\title{
PENDIDIKAN ANAK USIA DINI DI AWAL SEKOLAH DASAR MELALUI JOYFULL LEARNING: CATATAN KRITIS TERHADAP PEMBELAJARAN MENGGAMBAR ANAK
}

\author{
Nur Hamzah \\ Fakultas Tarbiyah dan Ilmu Keguruan (FTIK) \\ Institut Agama Islam Negeri (IAIN) Pontianak
}

\begin{abstract}
One of the urgent aspects which has to be provided by adults in a child's potency is the ability of drawing. Furthermore, the importance of drawing has a relevancy with the motoric trait development in children. Besides, drawing is able to enhance the ability of right brain as a visualization. This brain, moreover, has an essential part to strengthen all of intellectual activities. Nevertheless, it is slightly hard to expect that drawing will maximally contribute in children especially in an elementary school. Drawing which has been done in the elementary school is unfortunately accomplished without a construction concept by the teacher. This writing is a critical annotation to a drawing lessonat school, especially in early childhood education programs.
\end{abstract}

\section{Keywords:}

Early childhood education, Drawing lesson

\section{PENDAHULUAN}

Dalam pelaksanaan pendidikan di Indonesia, konsep dan batasan anak usia dini agak sedikit berbeda dibanding dengan beberapa negara lain terutama Eropa. Di Indonesia batasan umur anak usia dini adalah dari umur 0-6 tahun, sementara di banyak negara lain mulai umur 0-8 tahun sesuai konvensi anak dunia. Perbedaan batasan usia sebetulnya tak jadi masalah kalau konsep pendidikan dan prinsip pembelajaran anak usia dini diterapkan dalam proses pembelajaran pada anak usia 6-8 di kelas awal sekolah dasar. Namun kenyataan di lapangan berkata lain, bahwa di kelas awal 1, 2 dan 3 pembelajarandilakukan sebagaimana di kelas atas. Wal hasil pembelajaran bagi anak menjadi momok dan menengangkan karena konten materi yang disajikan terlalu padat. Di tambah lagi penyajian dan tuntutan kompetensi yang cendrung tidak seimbang yakni dengan stressing aspek kognitif saja. Anak oleh guru dituntut menghapal pengertian, konsep, bilangan dan lain sebagainya.

Permasalahan tidak berhenti di situ, bahwa guru dalam proses pembelajaran di kelas awal sekolah dasar masih tampil dengan pendekatan, metode juga strategi konvensional yakni ceramah dan hapalan. Metode ini tentu saja sangat tidak pas dengan karakteristik perkembangan anak usia 6-8 tahun. Wal hasil pembelajaran menjadi kegiatan yang tidak nyaman, tidak menyenangkan dan tidak menarik.Padahal, menurut konsep PAUD yang sebenarnya, mereka seharusnya dikondisikan dalam suasana belajar aktif, kreatif, dan menyenangkan lewat berbagai ragam metode seperti permainan, bercerita, menyanyi, gerak dan menggambar.

Berangkat dari problem tersebut, penulis ingin menawarkan rancang ulang konsep pembelajaran bagi siswa kelas awal sekolah dasar yakni di kelas 1 dan 2. Berdasarkan karakteristik umur dan perkembangan psikologisnya, anak pada kelas 1 dan 2 adalah anak usia dini, oleh sebab itu konsep pendidikan dan pembelajarannya niscaya menggunakan konsep dan pembelajaran PAUD. Prinsip paling dasar dalam proses pembelajaran PAUD adalah bahwa kegiatan pembelajaran harus menjadi sebuah kegiatan yang menyenangkan (Joyfull).

Pertanyaan berikutnya adalah mengapa konsep ini ditawarkan? Anak adalah sosok individu yang sedang menjalani suatu proses perkembangan tercepat dalam kehidupannya. Perkembangan itu meliputi perkembangan fisik, kognitif, sosial dan mental. Karena keistimewaan 
inilah maka masa usia 0-8 tahun disebut oleh para ahli dengan periode emas (Golden Period). Disebut periode emas karena pada masa ini anak sangat peka terhadap segala macam rangsangan dan stimulus dari luar yang datang kepadanya. Bayangkan saja, otak anak umur 8 tahun telah mencapai $80 \%$ volume otak orang dewasa, dengan demikian untuk umur selanjutnya tinggal menambah $20 \%$ saja. Demikian pula pada aspek perkembangan lainnya.

Karena periode 0-8 tahun adalah periode emas, maka perkembangan individu selanjutnya secara fundamental sangat ditentukan pada saat ini. Berbagai hasil penelitian menunjukkan usia dini merupakan masa peka yang sangat penting bagi pendidikan anak. Pada masa ini tempaan dapat memberikan bekas yang kuat dan tahan lama. Kesalahan dalam menempa akan memberikan efek negatif jangka panjang yang sulit diperbaiki. J.J. Rousseau menggambarkan masa peka tersebut ibarat saat yang tepat bagi tukang besi untuk menempa besi yang ia panaskan. Para penempa besi tahu betul kapan besi harus ditempa. Terlalu awal ditempa, besi sulit dibentuk dan dicetak. Sebaliknya, apabila terlambat menempa maka besi akan hancur. Demikian halnya pada manusia, saat yang paling baik dan tepat untuk memperoleh pendidikan adalah pada usia dini (Suyanto, 2005). Berdasarkan hal ini maka sebagai orang tua, pendidik dan masyarakat, kita berkewajiban memfasilitasi anak untuk mengembangkan potensi dirinya secara maksimal dan alamiah. Menurut Pestalozi, orang dewasa harus membantu anak agar dapat menolong dirinya sendiri.

Salah satu aspek penting yang harus dibantu orang dewasa adalah kemampuan menggambar pada anak. Pentingnya menggambar karena menggambar terkait dengan perkembangan motorik kasar dan halus seorang anak. Selain itu, menggambar dapat meningkatkan kemampuan otak kanan anak untuk visualisasi, yang pada akhirnya memiliki peranan sangat penting untuk meningkatkan semua aktivitas intelektual. Hanya saja jika melihat kegiatan menggambar pada sekolah dasar, sepertinya kita sulit berharap menggambar akan memberikan manfaat maksimal. Menggambar yang dilakukan oleh anak tanpa konstruk konsep dari gurunya. Guru hanya meminta anak menggambar dan yang lebih sering adalah gambar pemandangan. Saat mengambar tersebut hampir rata-rata siswa kita menggambar dengan konsep yang sama yaitu dua gunung, matahari, burung, jalan, sawah dan pohon. Rasanya menurut penulis seakan hal ini menjadi sesuatu yang turun temurun diwariskan, karena memang mulai dari orang tua dan juga guru saat memberikan contoh menggambar pemandangan, yang diberikan adalah hal tersebut diatas. Wal hasil anak hanya memiliki konsep tunggal tentang gambar pemandangan. Tidak berhenti disini, banyak lagi kasus kegiatan menggambar yang menurut kajian keilmuan keliru. Hal ini bukan tanpa sebab, salah satu faktornya adalah bahwa guru memang tidak mengetahui bagaimana cara mengajar menggambar yang benar. Dalam kajian berikut penulis ingin sharing tentang bagaimana secara konseptual kegiatan pembelajaran yang harus dilakukan oleh guru atau orang dewasa pada anak kelas awal sekolah dasar, khususnya lagi pada kegiatan/pembelejaran menggambar.

\section{Karakteristik Anak Usia Dini}

Dalam pandangan psikologi, anak usia dini memiliki karakteristik yang khas dan berbeda dengan anak lain yang berada di atas usia 8 tahun. Karakteristik yang khas tersebut menurut Richard D. Kellough (1996) adalah: bahwa anak itu bersifat egosentris, anak memiliki rasa ingin tahu yang besar, anak adalah makhluk sosial, anak bersifat unik, anak pada umumnya kaya akan fantasi dan anak memiliki daya konsentrasi yang pendek.

\section{Tinjauan Psikologi Perkembangan Anak Usia 6-8 Tahun}

Di Indonesia, usia anak 6-8 tahun merupakan masa peralihan dari pra-sekolah ke masa sekolah dasar. Selain itu, masa ini juga dikenal dengan masa transisi peralihan dari masa kanakkanak ke masa-masa awal pubertas. Ada beberapa karakteristik perkembangan pada masa anak usia 6-8 tahun, beberapa diantaranya adalah:

Perkembangan fisik. Peningkatan tinggi badan setahun sekitar 5-6 cm. Bentuk badan mempengaruhi tinggi dan berat badan. Secara umum perkembangan fisik berjalan seiring dengan perkembangan mental. Perbedaan pertumbuhan fisik antara laki-laki dan perempuan menjadi lebih 
nyata. Umumnya anak perempuan lebih cepat daripada anak laki-laki, tetapi setelah mengalami masa pubertas, anak laki-laki yang lebih cepat pertumbuhannya.

Perkembangan kognitif. Jika mengacu kepada pendapat Piaget, maka anak usia 6-8 tahun berada pada 2 masa berbeda yakni 6-7 tahun masa pra-operasional dan 7-8 tahun adalah masa operasional kongkrit. Pada ranah yang lebih sederhana, usia 6-8 tahun sesungguhnya adalah masa transisi dari pra-operasional ke operasional kongkrit. Ciri utama periode pra-operasional adalah anak mulai mengenal simbol, kemudian menggunakan fungsi simbolisasi tersebut. Menggunakan kata-kata, bermain mobil-mobilan menggunakan kursi dan lain sebagainya adalah contoh periode ini. Pada periode ini, anak juga mulai mengerti dasar-dasar pengklasifikasian.

Adapun ciri pokok masa operasional kongkrit adalah bahwa anak dapat mulai berpikir logis dan kongkrit, pengklasifikasian sudah mulai rumit, mampu membaca, dapat berbahasa seperti orang dewasa, bisa bercerita serta mampu membedakan anara hal yang serius dan lucu.

Perkembangan motorik, pada usia 6 tahun ke atas umumnya anak telah dapat mengkoordinasikan tangan dengan panca inderanya, misalnya bermain bola, bermain game di komputer dan lain-lain. Pada tahap ini sudah sangat bisa anak diajarkan berlari lurus tanpa jatuh, mewarnai dan termasuk menggambar.

Perkembangan bahasa dan komunikasi. Ketika memasuki bangku sekolah dasar, mereka memperluas relasi sosialnya dan diajarkan banyak kosakata baru maka perbendaharaan kata anak bertambah sangat drastis. Paling tidak kosakata anak telah mencapai 14.000 kata, kemudian penggunaannya juga telah menyerupai kalimat orang dewasa. Pada masa awal ini juga ternyata anak suka menggunakan bahasa rahasia sebagai alat berkomunikasi dengan sesama mereka.

Perkembangan sosio emosinal. Menurut Sigmund Freud, usia 6-8 tahun masuk kategori masa laten (6-12 tahun). Pada masa ini kehendak dan aktivitas sexsuil anak tidak sama seperti masa falik, ia terpendam dan tidak muncul kepermukaan karena anak sangat disibukkan dengan aktivitas sosialnya. Anak telah berorientasi dan bersosialisasi dengan lingkungan di luar rumah. Mereka mulai berteman dan menyesuaikan dengan lingkungan sosial.

Lain lagi menurut Erikson, usia 6-8 tahun masuk periode Industry vs inferiority (tekun vs rasa rendah diri). Adapun ciri-ciri masa ini adalah: anak mulai melakukan interaksi sosial, mengembangkan perasaan bangga terhadap keberhasilan dan kemampuan mereka, anak yang didukung dan diarahkan oleh orang tua dan guru membangun peasaan kompeten dan percaya dengan keterampilan yang dimilikinya. Anak yang menerima sedikit atau tidak sama sekali dukungan dari orang tua, guru, atau teman sebaya akan merasa ragu akan kemampuannya untuk berhasil.Prakarsa yang dicapai sebelumnya memotivasi mereka untuk terlibat dengan pengalamanpengalaman baru.

Ketika beralih ke masa pertengahan dan akhir kanak-kanak, mereka mengarahkan energi mereka menuju penguasaan pengetahuan dan keterampilan intelektual. Permasalahan yang dapat timbul pada tahun sekolah dasar adalah berkembangnya rasa rendah diri, perasaan tidak berkompeten dan tidak produktif.Erikson yakin bahwa guru memiliki tanggung jawab khusus bagi perkembangan ketekunan anak-anak.

Perkembangan moral. Penilaian baik dan buruk telah dapat dilakukan oleh anak dan mereka mulai dapat mempertimbangkan berbagai situasi khusus yang mendasari satu peristiwa atau perilaku. Anak juga memahami bahwa penilaian baik dan burukdapat berubah. Konsep moral seperti ini banyak dipengaruhi oleh kelompok sebayanya. Secara rinci Koblberg menyebutkan perkembangan moral anak periode ini yaitu: anak memahami adanya peraturan/norma standar yang harus diikuti, anak bereaksi sesuai konsekuensi yang diterima dan anak mengikuti apa yang didengar/dilihatnya.

\section{Tahapan Perkembangan Kemampuan Menggambar Anak}

Lowenfeld dan Brittain (1982) paling tidak mengidentifikasi tahap perkembangan menggambar pada anak menjadi empat tahap yang meliputi: Scribbling (tulisan cakar ayam/tak beraturan), preschematic, schematic dan menggambar realis. 
Tahap pertama Scribbling, dimulai saat anak usia 13 bulan. Sebelumnya, anak hanya memasukkan krayon atau pensil di mulut mereka. Sekitar usia 13 bulan, anak mulai membuat tanda dengan krayon dan pensil tersebut. Tulisan pertama umumnya berbentuk zigzag, belum mempunyai bentuk yang nyata. Kellogg (1970) pernah menguji (menilai) tulisan tak beraturan anak tersebut dan membuat kesimpulan bahwa anak selalu membuat pola tak beraturan, dimana hal ini dapat diidentifikasi melalui sebuah observasi. Setelah mamasuki usia 3 tahun, anak mulai membuat gambar yang berpola, kebanyakan adalah lingkaran.

Sekitar umur 4 tahun, anak mulai mencoba menggambarkan benda-benda dilingkungannya yang biasa mereka lihat. Tahapan ini disebut dengan preschematic. Kellogg (1970) mengatakan bahwa gambar pertama manusia yang dibuat oleh anak berasal dari lingkaran dan garis yang telah mereka biasa buat sebelumnya pada tahap scribbling. Anak-anak juga kadang menggambar objek lain yang berasal dari apa yang pernah mereka alami dari lingkungannya seperti binatang atau objek-objek lain dengan menggunakan bentuk/pola dasar yang sama. Warna-warna yang digunakan pada gambar mereka ini tidaklah realis (nyata) dan biasanya figur (objek gambar) ditempatkan secara acak di satu halaman.

Sekita umur 7 tahun, anak memasuki tahap schematic, dimana mereka mulai menggambar pola/bentuk yang pasti yang menggambarkan lingkungannya. Pada tahap ini, anak kembali mengulangi bentuk dasar yang sama ketika menggambar manusia, pohon atau burung. Figur atau objek sering kali dibuat diatas garis dan ditempat secara acak di suatu halaman; boleh jadi garis itu sendiri memang ditempatkan secara acak atau di tepi sudut sebuah kertas. Anak pada tahap ini seringkali mewujudkan (menggambar) objek berdasarkan sudut pandang mereka yang berbeda sama sekali dari cara pandang orang dewasa. Di tahap ini motorik anak sudah lebih berkembang. Ia bisa mengendalikan tangan dan menuangkan imajinasinya dengan lebih baik. Di tahap ini anak menggambar dengan penekanan pada bagian yang aktif dan sering melupakan beberapa bagian. Contoh, jika anak menggambar orang, maka penekanan dilakukan pada bagian kepala, tangan dan kaki. Sering kali kita melihat anak pada tahapan ini menggambar orang sebagai satu keutuhan lingkaran dengan mata, tangan dan kaki yang juga menempel pada lingkaran tersebut. Pada tahap ini anak lebih mengutamakan hubungan gambar dengan objek daripada hubungan warna dengan objek. Kerap kali kita temukan gambar dengan warna yang tidak sesuai aslinya. Umpama, langit warna merah, jalan warna kuning, dan sebagainya. Objek gambar pun masih dari objek-objek yang ada di sekitarnya, seperti orangtua, binatang peliharaannya, dan lainnya. Maka dari itu, orangtua perlu mengenalkan berbagai hal dan objek-objek yang dapat dieksplorasi oleh anak untuk dituangkan dalam bentuk gambar.

Sekitar umur 9 tahun, anak memasuki tahap menggambar realis. Mereka mulai membuat gambar lebih kecil danmemasukkan/mempunyai banyak detail; mereka juga tidak lagi gemar mendiskusikan pekerjaannya dengan orang dewasa. Jangan malas ya mas, terus saja melakukan aktivitas tiada henti agar yang menjadi cita-cita tercapai

\section{Memahami dan Memaknai Gambar Anak}

Menggambarbagianakadalah mencurahkanapa yang dialami, dipikirkan, diingkan dan diimajinasikannya. Olehsebabitubagiseorangdewasa, kita seharusnya membiarkan secara bebas kepada anak apa yang hendak ia gambar. Termasuk hal yang paling harus dihindari adalah menggambar terpola, dimana guru atau orang dewasa meminta anak untuk menggambar sesuai dengan apa yang diinginkan oleh orang dewasa tersebut. Ini banyak terjadi, coba kita perhatikan masih banyak anak menggambar pemandangan dengan 2 gunung dan matahari ditengahtengahnya. Gunung diwarnai biru, awan biru, jalan hitam dan lain sebagainya. Ini fakta bahwa anak hanya mempunyai satu konsep tentang pemandangan. Bisa jadi karena orang dewasa yang memasukkan konsep ini secara paksa, bahwa gung harus dua, bahwa laut harus biru dan lain-lain. Kemungkinan lain adalah karena orang dewasa tidak mengarahkan.

Pada saat melakukan studi di strata dua tahun 2008 lalu, peneliti pernah melakukan penelitian kecil tentang pola gambar anak di sekolah dasar. Dalam penelitian tersebut pada awalnya 
peneliti meminta anak seluruhnya menggambar pemandangan, pada hari berikutnya anak diminta menggambar apa saja yang mereka alami baik saat di rumah, di sekolah, di taman dan lain sebagainya. Beberapa dari hasil gambar anak tersebut dapat kita lihat sebagai berikut:

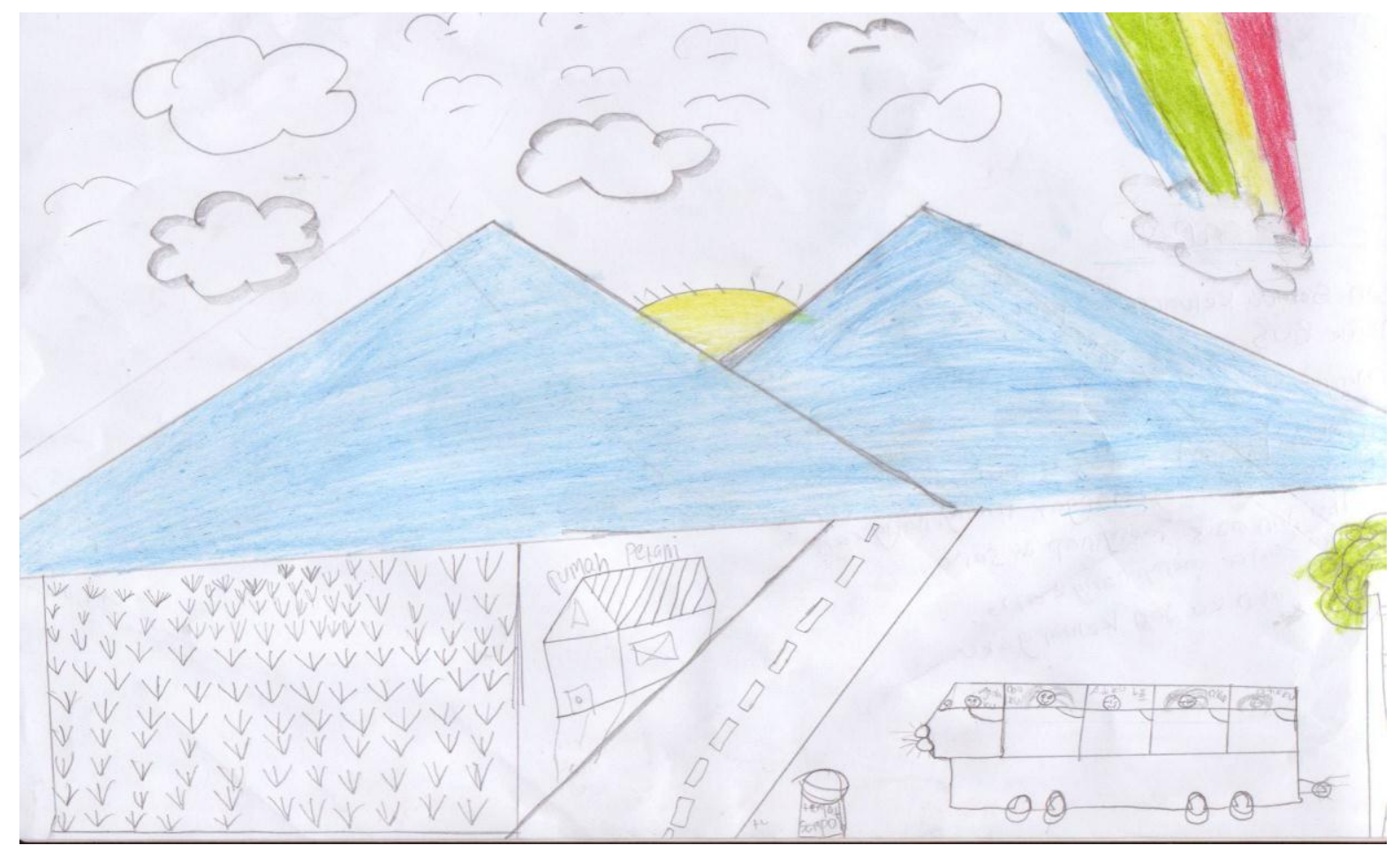

Gambar 1

Gambar ini dibuat oleh Sri Devi umur 7 tahun, dan gambar yang dibuatnya sama dengan pola yang penulis sebutkan diatas. Tidak hanya Sri Devi, banyak anak juga menggambar hal serupa. Jika konsep menggambar ter-pola ini terus dipelihara, menurut Gerda, dikhawatirkan kelak anak-anak mengalami hal-hal seperti berikut:

1. Tidak kreatif. Pola menggambar yang kaku membuat pemikiran anak jadi terstruktur, "Awan itu harus biru, kalau rumput ya hijau!" Lama-lama ia tak mampu mengembangkan dirinya dan jadi tidak kreatif. Aktivitasnya pun jadi monoton sehingga membuatnya mudah jenuh.

2. Tak mampu memecahkan masalah. Jika menghadapi masalah, anak tak mampu mencari solusi pemecahannya dan langkah-langkah alternatif. Solusi yang dijalankannya sama seperti yang biasa dilakukan orang lain ketika menghadapi masalah. Ujung-ujungnya kalau anak menemui masalah, dia akan panik dan tak mampu menyelesaikan masalah tersebut.

3. Tak bisa mandiri. Di kemudian hari, anak tak mampu mandiri, selalu bergantung pada orang lain, entah itu orang tua atau saudaranya. Akibat tak punya sikap yang jelas, maka anak mudah diintervensi atau dibujuk orang lain. 


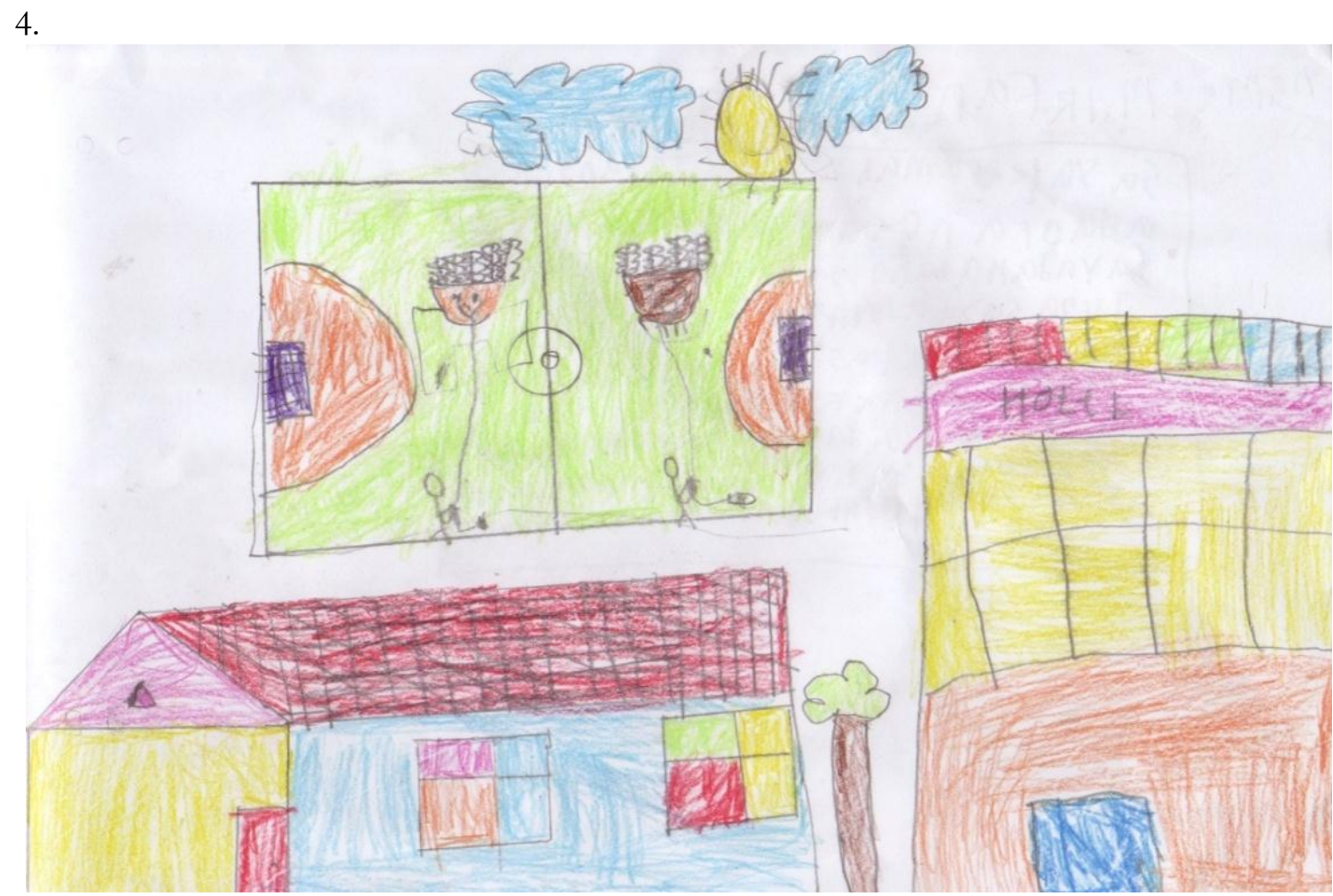

Gambar 2

Gambar 2 ini perintahnya adalah anak diminta menggambar bebas. Ada banyak objek yang digambar oleh anak: lapangan bola, rumah, hotel, pohon dan dua orang sedang bermain layangan. Lukisan ini digambar oleh M. Irfan yang berusia 8 tahun, ketika ditanya mengapa ia menggambar demikian, ia menjawab bahwa gambar itu adalah lukisan ketika ia bersama orang tua dan saudaranya ke rumah neneknya. Di rumah neneknya tersebut banyak pohon di kanan kiri, kemudian dibelakang ada lapangan besar yang digunakan untuk bermain termasuk bermain sepak bola. Saat ia lapangan tersebut, Irfan menemukan banyak anak sedang bermain layangan. Dikanan rumah neneknya ada satu hotel besar bertingkat.

Lukisan yang dibuat oleh Irfan adalah lukisan dari pengalamannya. Pengalaman yang dilihat dan dilakukannya digambar menjadi satu lukisan utuh. Tampak bahwa gambar tersebut telah memiliki pola jelas karena objek digambar sesuai dengan aslinya. Satu yang membedakan adalah bahwa warna yang digunakan tidak sebagaimana warna aslinya, hal ini karena anak tidak memikirkan bagaimana mencocokkan warna dengan objek tapi bagaimana objek dibuat semirip mungkin dengan yang sesungguhnya. 


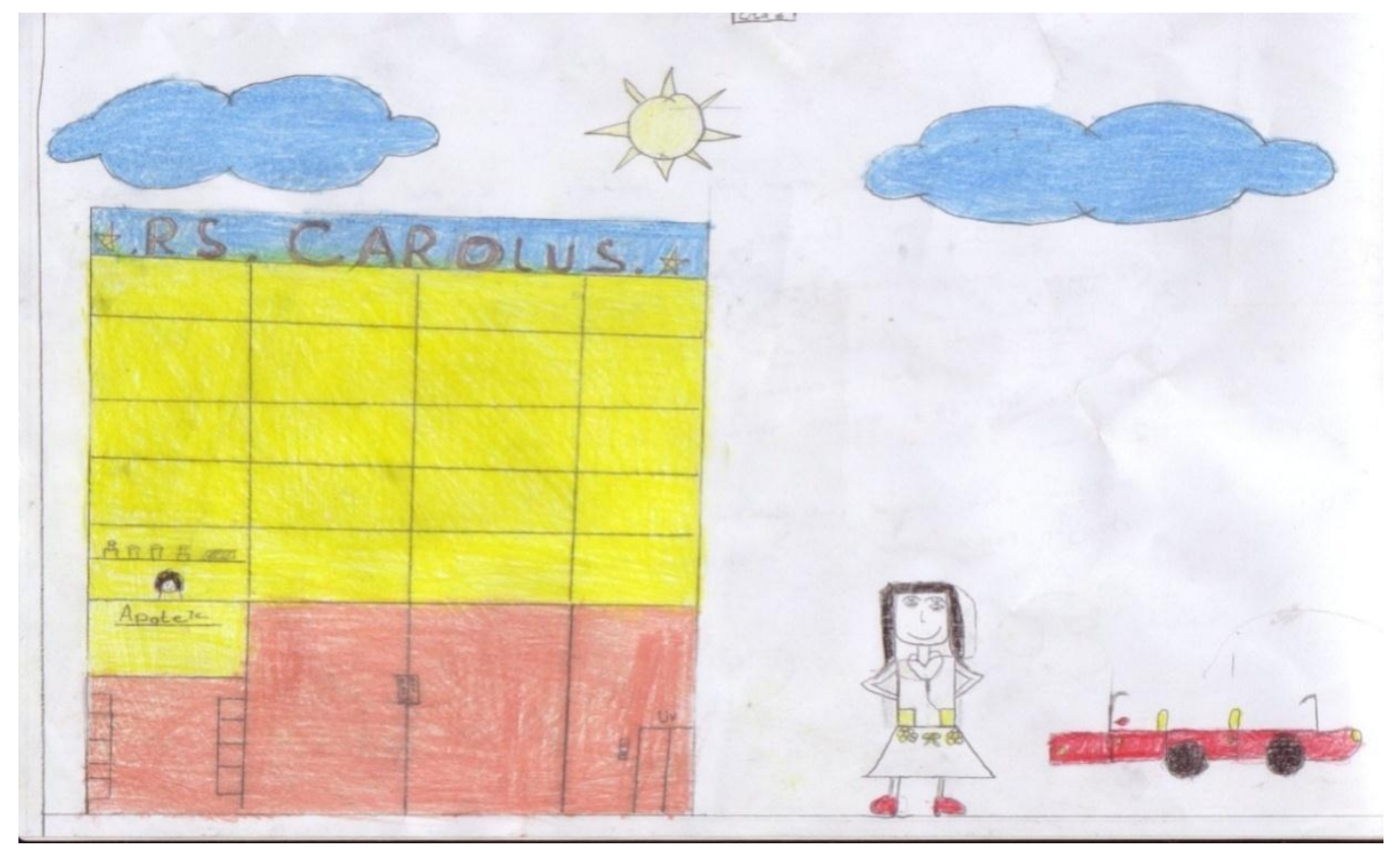

Gambar 3

Gambar 3 ini dibuat oleh Nurul usia 7 tahun lebih. Ia menggambar rumah sakit St. Carolus, disampingnya ada seorang dokter dan mobil. Selain gambar bangunan megah rumah sakit, Nurul juga melukis apotik yang sedang dijaga oleh seorang apoteker. Ketika ditanya mengapa Nurul membuat lukisan ini, jawab Nurul karena ia ingin menjadi seorang dokter kelak. Selain itu karena Nurul juga sering ke rumah sakit ini saat ia, atau adik-adiknya sakit. Ia dilahirkan di rumah sakit ini, begitu juga saudara-saudaranya. Melihat profesi seorang dokter yang selalu membantu orang sakit, ia juga menjadi ingin seperti dokter.

Apa yang digambar oleh Nurul adalah kombinasi dari pengalaman dan imaginasinya. Karena rumah sakit adalah gedung dengan model kotak, sehingga Nurul tidak kesulitan melukis ulang. Ia juga menggambar dokter yang sedang bekerja didalamnya, tetapi ia gambar berdiri sendiri disamping. Tampak ciri yang paling menonjol dari gambar dokter tersebut adalah kepalanya yang besar. Orang tidak digambar secara proporsional sebagaimana aslinya. Hal ini sedemikian rupa karena saat anak mempersepsikan manusia, yang fokus, menarik dan paling diingat bagi mereka adalah bagian kepala. Pada kegiatan yang ke-2 ini anak sudah diarahkan oleh penulis sehingga muncul gambar yang beragam dan variatif. Hal ini juga lah yang seharusnya dilakukan oleh guru, orang tua dan orang dewasa lainnya.

\section{PENUTUP} diantaranya:

Menggambar adalah penting, karena itu ada beberapa hal yang diperhatikan juga dilakukan

1. Menggambar di ruang terbuka. Belajar menggambar bisa dilakukan di luar ruang. Malah konsep aktivitas luar ruang ini sudah banyak diterapkan banyak sekolah. Anak diajak ke sebuah taman, umpamanya, untuk selanjutnya dibolehkan menggambarkan apa saja yang dianggapnya menarik. Dari situ anak sekaligus belajar mengidentifikasi sesuatu, bahwa pohon pisang itu ternyata berbeda dari pohon mangga, misalnya.

2. Menggambar sesuai yang dipersepsikan.Jika di luar kelas tak memungkinkan, di dalam kelas pun pelajaran menggambar tetap dapat berlangsung. Yang penting, anak dibebaskan menggambar objek dari sudut pandang atau sisi yang dilihatnya. Jadi sah-sah saja kalau ia 
menggambar komputer tidak dari sisi depan melainkan dari samping kiri atau kanan. Dari situ masing-masing anak dapat mengembangkan daya kreativitasnya. Hasil gambarnya pun tidak akan seragam karena persepsi mereka juga berbeda-beda. Jadi beri saja sehelai kertas gambar. Lalu biarkan anak bebas mencipta atau menggambar sesuai imajinasinya.

3. Membentuk tim. Proses belajar menggambar saat ini kebanyakan masih bersifat individual. Untuk itu, latihlah anak untuk menggambar dalam bentuk tim. Konkretnya, satu kertas gambar dapat dikerjakan tiga orang dengan satu topik tertentu. Manfaatnya, anak dapat belajar berbagi tugas, bersosialisasi, berkolaborasi, belajar melawan sifat egois, dan mau menerima pendapat atau gagasan temannya.Beri kebebasan pada masing-masing anak untuk memilih bagian kertas mana yang mau ia coret-coret sebagai gambaran idenya; bagian tengah, kiri atau kanan. Akan lebih baik, bila ia didorong untuk tak melulu memilih salah satu bagian kertas saja, misalnya bagian tengah terus, umpamanya. Sesekali minta ia mencoba menggambar di bagian pinggir. Faedahnya, anak jadi mengenal berbagai situasi dan kondisi. Namun terlepas dari itu, karya yang dihasilkan bersama bisa menjadi kebanggaan bersama pula. Apalagi kalau proyek tim ini berhasil menjuarai suatu lomba menggambar.

4. Jangan ada intervensi. Dalam perlombaan menggambar biasanya orang tua yang ikutikutan mengintervensi atau nimbrung mencampuri apa yang digambar anak. Dari yang sekadar tunjuk-tunjuk mengomandoi anak sampai ada yang membantu melengkapi gambar anaknya. Hal seperti itu sama saja dengan mendikte anak agar menggambar sesuai keinginan orang tua. Kalau hal ini jadi kebiasaan, dalam artian anak selalu didikte, dipandu, bahkan dibantu saat menggambar, jangan salahkan kalau kelak ia selalu menunggu instruksi orang tuanya dalam berbuat sesuatu. Anak takut melakukan sesuatu yang tak diminta orang tua karena takut salah. Dengan kata lain ia tetap kerdil sekalipun nanti sudah menginjak usia remaja atau dewasa karena selalu bergantung pada orang tuanya.Untuk menghindarinya, mulai saat ini biarkan ia mencurahkan apa yang menjadi imajinasinya dalam bentuk gambar saat perlombaan berlangsung. Dari situlah anak belajar bertanggung jawab mengerjakan sebuah penugasan.

5. Beri pujian jangan celaan. Setelah anak menyelesaikan gambarnya, berilah pujian. "Gambarmu bagus sekali. Tapi mataharinya kok kurang bulat. Coba deh kamu buat lebih bulat." Hindari perkataan seperti, "Aduh, gambar kepala orangnya kok peyang sih!" Intinya, guru dan orang tua mesti menerapkan nuansa edukatif dalam rangka didaktik menggambar. Kalau hasil karya anak dipuji, dia akan merasa percaya diri dan merasa bisa melakukan sesuatu serta bangga dengan apa yang dilakukannya. "Jangan lihat hasil akhir bahwa gambar itu jelek tapi lihat prosesnya. Hargai setiap usaha anak dalam menggambar."

6. Biarkan anak memilih pensil warna sendiri.Ada kalanya guru menerapkan metode dengan cara hanya memberikan warna pensil yang terbatas kepada anak-anak. Padahal dengan begitu, justru anak tak bisa mengeksplorasi imajinasinya. Dia merasa dikekang dan tak bisa menciptakan sesuatu dengan optimal. "Sebaiknya berikan semua pensil warna dan biarkan anak memilih sendiri pensil warna yang disukai sesuai getaran jiwanya."

7. Ajak anak untuk menjelaskan karya gambarnya.Usai menggambar, mintalah si prasekolah untuk menjelaskan apa saja yang digambarnya. Upaya ini merupakan cara untuk melatih kemampuan berbicara dan keberanian mengungkapkan pikiran dan gagasannya dengan lisan.***

\section{REFERENSI}

Abubakar Bardja, Psikoligi Perkembangan Tahap-tahap dan Aspek-aspeknya dari 0 tahun sampai akbil Baliqh, Studia Press, Jakarta, 2005

Elizabeth Hurlock, Psikologi Perkembangan Suatu Pendekatan Sepanjang Rentang Kebidupan, Eralangga, Jakarta, 2007.

Jo Ann Brewer, Early Childhood Education; Preschool Through Primary Grades, 2007 
Sofia Hartati, Perkembangan Belajar Anak Usia Dini, Depdiknas, Jakarta, 2005

Singgih Gunarsa, Dasar dan Teori Perkembangan Anak, PT. BPK Gunung Mulia, Jakarta, 1990

Yuliani Nurani Sujiono, Menu Pembelajaran Anak Usia Dini, Yayasan Citra Pendidikan Indonesia, Jakarta, 2005 